\title{
Free and Esterified Carotenoids in Ornaments of an Avian Species: The Relationship to Color Expression and Sources of Variability
}

\author{
Esther García-de Blas ${ }^{1, *}$ \\ Rafael Mateo ${ }^{1}$ \\ Javier Viñuela ${ }^{1}$ \\ Lorenzo Pérez-Rodríguez ${ }^{2,3}$ \\ Carlos Alonso-Alvarez ${ }^{1}$ \\ ${ }^{1}$ Instituto de Investigación en Recursos Cinegéticos, Consejo \\ Superior de Investigaciones Cientificas, Universidad de \\ Castilla-La Mancha, Junta de Comunidades de Castilla-La \\ Mancha, Ronda de Toledo s/n, 13071 Ciudad Real, Spain; \\ ${ }^{2}$ Department of Evolutionary Ecology, Museo Nacional de \\ Ciencias Naturales, c/José Gutiérrez Abascal, 2. 28006 \\ Madrid, Spain; ${ }^{3}$ Centro de Investigação em Biodiversidade e \\ Recursos Genéticos, Campus Agrário de Vairão, Rua Padre \\ Armando Quintas, 4485-661 Vairão, Portugal
}

Accepted 6/1/2013; Electronically Published 8/14/2013

\begin{abstract}
Many animal species show ornaments with yellow-orange-red colors produced by carotenoid pigments. Such traits have evolved as reliable signals of individual quality because of the costs inherent to their production or maintenance. In animal tissues, carotenoids are often found combined with free fatty acids, as carotenoid esters, which may confer more stability to coloration than free carotenoids. Surprisingly, the potential relevance of carotenoid esterification in the expression of animal sexual signals has been virtually ignored. Moreover, the sources of variability of esterified carotenoid levels are barely known, because most studies have not quantified their concentrations. Here, carotenoids in the ornaments (bill, eye rings, and legs) of red-legged partridges Alectoris rufa were quantified in their free and esterified forms. Carotenoid ester levels were the best predictors of leg color, whereas the redness of the other traits was better explained by free carotenoids. Nonetheless, total carotenoid levels (the sum of free and esterified forms) were always significantly correlated to redness. Young partridges had lower levels of free and esterified carotenids in the legs than did older individuals. Also, wild animals had higher ester levels and a higher proportion of carotenoids in esterified forms in all traits than did captive partridges. Probable physiological mechanisms explaining these patterns are discussed.
\end{abstract}

\footnotetext{
*Corresponding author; e-mail: esther.garciablas@uclm.es.
}

Physiological and Biochemical Zoology 86(5):483-498. 2013. (C) 2013 by The University of Chicago. All rights reserved. 1522-2152/2013/8605-2171\$15.00. DOI: $10.1086 / 671812$

\section{Introduction}

Colors of yellow-orange-red ornaments in numerous animal species are produced by carotenoid pigments. Carotenoids are synthesized by plants and other autotrophic organisms (Goodwin 1984). Carotenoids have attracted the attention of researchers because animals can obtain them only from food sources and because they have physiological properties related to homeostasis, acting as antioxidants (Miller et al. 1996; Stahl and Sies 2003; Hill and Johnson 2012) and immune boosters (Lozano 1994; Chew and Park 2004). This implies that carotenoid-based traits could have evolved as sexual signals used in mate choice because they would reliably indicate the quality of the bearer (reviewed in Hill 2006). Conspicuous carotenoidbased traits should indicate that individuals with those traits are able to find the apparently scarce carotenoid resources in the environment ("good foragers"; Endler 1980; Grether et al. 1999) and/or are able to cope with the trade-off between investing carotenoids in signaling versus self-maintenance (Lozano 1994; Møller et al. 2000).

Carotenoids found in ornaments can be present as free or esterified forms (Czeczuga 1979; McGraw 2006). Esterification means that the hydroxyl groups present on the carotenoid end rings are bound to one or two fatty acids (monoesters or diesters; Tyczkowski and Hamilton 1986; McGraw 2006). The presence of carotenoid esters in sexual signals of animals has barely been addressed, because most studies use saponification to separate carotenoids from fatty acids during the analytical process. Only a few articles have reported the presence of carotenoid esters in animal ornaments. First, Czeczuga (1979) detected astaxanthin esters in bare parts of turkey Melleagris gallopavo, domestic geese Anser anser domesticus, domestic mallards Anas plathrhynchos domesticus, and domestic fowl Gallus gallus domesticus by means of early chromatographic techniques (thinlayer chromatography). Wedekind et al. (1998) reported that virtually all the astaxanthin, lutein, and tunaxanthin in the skin of male sticklebacks Gasterosteus aculeatus was present in esterified form (see also Pike et al. 2011). Casagrande et al. (2011) showed that lutein in eye rings of diamond doves Geopelia cuneata is also present in two unidentified esterified forms. García-de Blas et al. (2011) were the first to identify those free fatty acids forming carotenoid esters in an ornament (the leg) of the red-legged partridge Alectoris rufa. Finally, San-Jose et al. (2012) recently reported the presence of unidentified lutein esters in the skin of common lizards Lacerta vivipara. Thus far, 
all of the esterified carotenoids found in animal tissues are xanthophylls (i.e., compounds containing oxygen), one of the two main carotenoid families (Britton et al. 2004).

Given the scarce information available, little is known about the contribution of esterified carotenoids to color expression in animals (McGraw 2006) or their potential influence on the reliability of carotenoid-based ornaments as signals of individual quality. There is no evidence that esterification influences the hue of carotenoid-based ornaments (McGraw 2006). Nonetheless, esterification seems to improve pigment stability as reported in plants (Pérez-Gálvez and Mínguez-Mosquera 2005; Rao et al. 2007; Schweiggert et al. 2007) and probably favors solubility of carotenoids in lipidic cell membranes (Pintea et al. 2005; Heras et al. 2007). Variability of total amounts of carotenoids in the ornaments among individuals could thus be limited by the capacity to allocate only one of the two forms (free or esterified pigments) to the trait. Such a possibility would link the mechanism responsible for producing that particular carotenoid form (if costly) to individual quality and, ultimately, to signal reliability (Hasson 1997; Hill 2006).

Virtually nothing is known about what sources of variability influence the amount of free or esterified carotenoids deposited in ornaments. For instance, in birds, the influence of age on colored ornaments is well known, with young animals exhibiting paler carotenoid-based traits than mature animals (Deviche et al. 2008; del Val et al. 2010; Freeman-Gallant et al. 2010), but the contribution of carotenoid esterification is unknown. It is also well known that animals, and particularly birds, may lose color under captivity conditions (Weber 1961; Brush 1981; Hill 2006b). This color loss was initially attributed to the low carotenoid content in their diet (Hill 1992), a lack of availability of those specific carotenoids that provide color to ornaments (Hill 2006), and stress due to captivity (Hudon 1994). In the last case, it was hypothesized that stress would inhibit those enzymes in charge of biotransforming dietary carotenoids into pigments deposited in ornaments (Hill 2006). However, we do not know whether carotenoid esterification could to some extent explain differences between captive and wild birds, which would contribute to clarifying the mechanism involved in signal expression.

In the red-legged partridge $A$. rufa, the bill, eye rings, and legs are pigmented by carotenoids (Pérez-Rodriguez and Viñuela 2008). In this species, several links between redness and individual quality have been reported. Experiments have shown that redder partridges have a better body condition and immune capacity (Perez-Rodriguez and Viñuela 2008; PérezRodríguez et al. 2008; Mougeot et al. 2009) and undergo less oxidative stress during an inflammatory response (Pérez-Rodríguez et al. 2008). Moreover, those birds experimentally exposed to oxidative stress produced paler carotenoid-based traits (Alonso-Alvarez and Galvan 2011). Finally, we have recently shown that females mated with males whose red eye rings and bills were artificially intensified produced more eggs than females mated with control males, which suggests that females indeed consider them as good mates and/or parents (AlonsoAlvarez et al. 2012).
Here, our aims were (1) to analyze how levels of both free and esterified fractions of carotenoids in ornaments are related to color expression and (2) to study the influence of age of birds and captivity conditions on the concentration of free and esterified carotenoids in ornaments.

\section{Material and Methods}

Samples

Samples were obtained from seven different free-living populations (minimum distance between them, $\sim 20 \mathrm{~km}$ ) and five farms located in the Castilla-La Mancha region in central Spain. Captive farm-bred partridges were housed in outdoor aviaries. They were euthanized by means of anesthesia (details in the appendix). In the case of wild partridges, body parts were provided by hunters on the day they were killed. Game management practices in those seven wild populations did not include restocking with farm-bred individuals. Samples from 118 captive and 51 wild birds were analyzed. Birds were genetically sexed using leg tissues and following the method of Fridolfsson and Ellegren (1999). The age of wild birds was unknown. Among captive birds, 65 partridges from two farms could be attributed to age categories (yearlings, $n=37$; birds $\geq 1 \mathrm{yr}$ old, $n=28)$.

Tissues from the red bare parts (bill, eye ring, and leg) were obtained from each wild animal ( $n=51$ in each case). Among captive partridges, bills from 111 birds, eye rings from 116 birds, and legs from 119 birds were used. All samples (from both captive and wild birds) were obtained from November 23 to March 16 (hunting season) in four different years (2008-2010 and 2012). These months cover winter and the mating period (Cramp and Simmons 1980). There was no significant difference in the Julian date of sampling dates between wild and captive birds $\left(F_{1,8.77}=0.16, P=0.697\right.$; mean $\pm \mathrm{SE}=356 \pm$ $17.5 \mathrm{~d}$ and $365 \pm 15.3 \mathrm{~d}$, respectively). Including sampling date as a covariate in the analyses did not influence the results (see "Statistical Procedures").

\section{Analysis of Color}

A photograph of the left side of the head and another photograph of the left leg were made for each bird. Initially, a Nikkon Coolpix 4500 digital camera was used (2008; 12 captive and 22 wild birds). It was substituted with an Olympus E-510 digital camera when the first camera was broken (2009-2012; 106 captive and 29 wild birds). Several pictures were lost because of damage to the memory card of the camera. These included all of the pictures from six wild and four captive birds, the bill and leg of one captive bird, and the eye ring and leg of another wild bird. Color measurements for each camera were standardized ( 0 mean $\pm 1 \mathrm{SD}$ ). Furthermore, a standard red reference (Kodak color card) was always placed close to the bird to correct for variability in environmental light (see "Statistical Procedures"). In addition, the camera was always coupled to a standard light unit (Repro Base with lights RB260 $2 \times 11 \mathrm{~W} 6,000^{\circ} \mathrm{K}$; Kaiser Fototechnik, Buchen, Germany), 
placing each individual at a fixed distance from the lens. Settings of shooting speed and diaphragm aperture were fixed. Photographs were analyzed by selecting the red area of the eye ring and bill (upper mandible) by means of Adobe Photoshop CS3 (Adobe Systems, San Jose, CA). Measurements were performed by a technician naive about the birds' identity. The RGB values for each area were registered, and the hue $\left({ }^{\circ}\right)$ values were calculated from these data with use of the algorithm described in Foley and Van Dam (1984). Additional details are provided in the appendix. Because low hue values conventionally indicate high levels of redness (Foley and Van Dam 1984), the sign of the variable was reversed to simplify interpretations. The term "redness" thus describes the inverse of hue (more intense red as opposed to orange).

Most of the variability in reflectance of carotenoid-based colors of red-legged partridge ornaments is distributed in the red part of the spectrum (625-700 nm; Perez-Rodriguez 2008; Alonso-Alvarez and Galvan 2011). Hence, we assume that our measurement technique effectively captured color variability of biological relevance in the traits studied (Butler et al. 2011; Pike et al. 2011; also see the appendix).

\section{Carotenoid Extraction}

The carotenoid extraction from integuments was performed following the method described by García-de Blas et al. (2011). New details are described here. The complete tissue of each bare part was used. Approximately $50 \mathrm{mg}$ of tissue for the eye rings (skin) and the bill (ramphotheca of upper mandible), respectively, was obtained. For podotheca (legs), approximately $100 \mathrm{mg}$ of skin including scales was used. Integument samples were extracted with $5 \mathrm{~mL}$ of hexane : tert-butyl methyl ether (TBME; $1: 1$ ) in an electric homogenizer (Ultra-turrax VDI 12, VWR, Barcelona) for $30 \mathrm{sec}$. The sample was kept on ice, avoiding exposure to light. The pooled extract was centrifuged $(2,026 \mathrm{~g}$ for $5 \mathrm{~min})$, and the supernatant was evaporated to dryness under a nitrogen stream. The pooled organic extract was then redissolved in an adequate amount of chromatographic phase A formed by $\mathrm{MeOH}$ : TBME : $\mathrm{H}_{2} \mathrm{O}(81: 15: 4)$ and acetone. For eye ring and bill, the volume was $200 \mu \mathrm{L}$ of phase A and $200 \mu \mathrm{L}$ of acetone; for the leg, the volume was $300 \mu \mathrm{L}$ for each. Carotenoid recoveries of this one-step extraction with respect to the total carotenoid obtained from consecutive reextractions of the same sample were calculated for 16 birds and were a mean $( \pm \mathrm{CV})$ of $86.8 \% \pm 3.3 \%$, $86.7 \% \pm 1.9 \%$, and $84.3 \% \pm 8.9 \%$ for bills, eye rings, and legs, respectively.

\section{Carotenoid Analyses}

This analysis was performed following García-de Blas et al. (2011). Briefly, an Agilent 1100 series system equipped with a diode array detector (DAD) and a column specific for carotenoids (C30, YMC Carotenoid $5 \mu \mathrm{m}, 250 \times 4.6 \mathrm{~mm}$ i.d.) was used. The injection volume was $20 \mu \mathrm{L}$. Phase A was $\mathrm{MeOH}:$ TBME: $\mathrm{H}_{2} \mathrm{O}(81: 15: 4)$, and phase $\mathrm{B}$ was
MeOH : TBME (10:90; phase B). Samples were initially eluted with $99 \%$ of phase A and $1 \%$ of phase B, changing by gradient to $44 \%$ of phase A and $56 \%$ of phase B in $39 \mathrm{~min}$, and reaching final conditions of $100 \%$ of phase B in $6 \mathrm{~min}$. The system then returned to initial conditions in $5 \mathrm{~min}$, and these were maintained for $5 \mathrm{~min}$ to stabilize the column. The flow was $1 \mathrm{~mL} / \mathrm{min}$. DAD conditions are specified in Garcíade Blas et al. (2011). The identification of free carotenoids and carotenoid esters was performed by comparison of retention times and UV-Vis spectra with commercially available carotenoid standards at a working concentration of $100 \mathrm{ng} / \mu \mathrm{L}$ in $\mathrm{MeOH}$ and by comparing with spectra available in the literature (Britton et al. 2004). Standards of lutein, canthaxanthin, zeaxanthin, astaxanthin, astaxanthin monopalmitate, and astaxanthin dipalmitate were purchased from CaroteNature (Lupsingen, Switzerland). Lutein and cantaxanthin concentrations were determined from serial dilutions of their standards and linear calibration adjustments. The other carotenoid molecules were quantified from quadratic calibration curves of astaxanthin standards (free and esterified forms). The identification of the second most abundant carotenoid present in the integuments of red-legged partridges is still pending (probably papilioerythrinone; E. García-de Blas, R. Mateo, and C. AlonsoAlvarez, unpublished data) and has been provisionally named carotenoid X (García-de Blas et al. 2011). Carotenoid X quantification was performed by means of astaxanthin curves, because the two carotenoids are closely related (García-de Blas et al. 2011). Other details of the procedure used for detecting and quantifying carotenoid esters are described in García-de Blas et al. (2011). The sum of the concentrations of each type of ester for each type of carotenoid was calculated. Thus, we determined the total concentration of carotenoid X monoesters and the total concentration of astaxanthin monoesters and diesters. Carotenoid concentration was expressed as micromoles per gram of tissue. Repeatabilities of carotenoid quantifications were determined on a subsample ( $n=16$ for each trait) analyzed twice ( $r=0.78-0.90 ; P<0.01$ for all).

\section{Statistical Procedures}

To analyze how the variability in free and esterified carotenoid levels influenced color, generalized mixed models (PROC Mixed; SAS, version 8; SAS Institute; Littell 2006) were used to find the carotenoid-based variable that best explained redness. All the analyses were separately performed for each ornament because of the different nature of each tissue (histological and structural differences or differential exposure to wear and abrasion). Redness was tested as the dependent variable, and redness of the red reference was included to correct for differences in light among pictures or sessions $(P<.05$ for all). The origin of the samples (five captive and seven wild populations) and the year of analysis (2008, 2009, 2010, and 2012) were always included in the models as random factors ( $P$ values ranged from 0.029 to 0.277 ). Concentrations of free carotenoid $\mathrm{X}$, astaxanthin, lutein, and cantaxanthin as well as concentrations of esterified carotenoid $\mathrm{X}$ and astaxanthin were 
added as covariates. Astaxanthin esters were tested by including the sum of the levels of monoesters and diesters as a covariate. In all statistical analyses, carotenoid values (free or esterified forms of the pigments expressed as micromoles per gram) were $\log$ transformed to meet the normality assumption. They were subsequently recalculated as the residuals from mixed models to control for the environmental variability (wild vs. captivity, fixed effects), population, and year of analysis (random factors). When obtaining residuals, each carotenoid type was tested as the dependent variable. Residuals were subsequently added to the models testing redness as covariates. The sex and Julian sampling date never influenced redness or carotenoid variables and were not included in final models $(P>0.10$ for all). All the models were calculated from saturated ones by removing nonsignificant variables sequentially by a backward stepwise procedure to find the best-fitted final model including only significant terms $(P<0.05)$. This model was then verified by the inverse forward stepwise procedure addition of variables. Furthermore, to evaluate possible problems of colinearity among covariates, we also calculated models testing each covariate separately to determine which term provided the lowest Akaike criterion (AIC) value. Conventionally, differences of $<2$ units of AIC indicate that models did not differ (Littell et al. 2006). Explained deviances (ED) from best models are provided.

Additionally, to determine whether levels of esterified carotenoids are better predictors of trait color than free carotenoids or total (free plus esterified) carotenoid values (i.e., the variable commonly used and obtained after carotenoid saponification), we first separately tested each term in generalized mixed models including redness as the dependent variable, the red reference as a covariate $(P<0.001$ for all), and the population and year of analysis as random factors ( $P$ values ranged from 0.031 to 0.299 ). Alternatively, we also tested total free and esterified carotenoids in the same model, noting which term prevailed. Carotenoid-related covariates were log transformed and calculated as residuals as previously described. AICs and EDs from best models are provided.

To analyze the influence of the age of birds (yearlings vs. $\geq 1$-yr-old birds) and environment (wild vs. captive) on redness and carotenoid composition, several generalized mixed models were performed. When analyzing redness, models included the redness of the reference as a covariate and the age or the environment as fixed factors. The age was tested on a known-age subsample of captive animals from the only population (Finca Dehesa de Galiana; Ciudad Real, Spain) in which both age classes were present (yearlings, $n=18$; $\geq 1$-yr-old birds: $n=$ 28 ). The sex was always added to the models, but it was removed when no trend to significance was detected $(P>0.1)$. Similarly, the Julian date of sampling was added as a covariate, although it was never significant $(P>0.10$ for all $)$ and was subsequently removed. In the case of models testing the effect of age, the year of analysis was the only random term ( $P$ values ranged from 0.121 to 0.483 ), because only one population was represented. In models that tested the environment (wild vs. captivity) as a fixed factor, the population and year of analysis were always included as random factors $(P$ values ranged from 0.020 to 0.48 ). To determine whether the age of birds or the environment influenced the rate of esterification in tissues, the rates of esterified forms of carotenoids (relative to total amounts) were tested as dependent variables in different models by using normal distribution and identity link (GLIMMIX procedure in SAS; Littell et al. 2006). They were also tested by using Poisson distribution and log link (also GLIMMIX in SAS), and similar results were obtained. In addition, some differences in redness and pigment composition among ornament types were tested by adding the bird identity to the models cited above $(P<.001$ for all). Differences are always provided as least square means \pm SE from models, taking into account random factors and any other term in the model. Degrees of freedom were always approximated by the Satterthwaite correction (Littell et al. 2006).

\section{Results}

\section{Carotenoid Description and Difference between Ornaments}

The same two main carotenoids (astaxanthin and carotenoid $\mathrm{X}$ ) in free and esterified forms described in García-de Blas et al. (2011) were found in all the ornaments and samples. Additionally, small quantities of lutein and cantaxanthin have now been detected (fig. 1). Astaxanthin and carotenoid $\mathrm{X}$ formed up to 13 different monoesters, and astaxanthin formed up to 17 different diesters. Lutein and cantaxanthin did not produce esterified compounds. The greater part of the total amount of carotenoids in the ornaments was esterified. Also, the degree of esterified versus total carotenoid levels significantly differed among ornaments $\left(F_{2,325}=7.13, P=0.001\right)$, with eye rings showing slightly higher rates compared with the other two traits (bill: $81.43 \% \pm 3.94 \%$; eye rings: $84.12 \% \pm 3.94 \%$; legs: $82.09 \% \pm 3.94 \%$; Tukey's post hoc comparisons: both $P$ values $<0.02)$. Redness did not differ between traits $\left(F_{2,301}=0.14\right.$, $P=0.872$ ). Concentrations of free and esterified carotenoids in a given trait were always positively correlated (all tests: $r>$ 0.55; $P<0.001$, for any tissue or compound).

\section{Predictors of Ornament Redness}

In the bill and eye ring, the level of free carotenoid $\mathrm{X}$ was the best predictor of redness (bill: $F_{1,136}=9.73, P=0.002$, slope $\pm \mathrm{SE}=0.438 \pm 0.141, \mathrm{ED}=6.8 \%$; eye ring: $F_{1,141}=$ $21.16, P<0.001 ;$ slope $\pm \mathrm{SE}=0.665 \pm 0.145, \mathrm{ED}=12.4 \%$; fig. $2 A, 2 B$ ), with both models providing the lowest AIC values (344.6 and 363.7, respectively), which were $>2$ units smaller than the best alternative models (i.e., cantaxanthin and carotenoid X esters as covariates: 348.5 and 365.8 , respectively, for each trait). In legs, the total amount of esterified astaxanthin (monoesters and diesters pooled) was the best predictor $\left(F_{1,138}=11.35, \quad P<0.001 ;\right.$ slope $\pm \mathrm{SE}=0.354 \pm 0.105$; $\mathrm{ED}=7.8 \%)$ with the lowest $\mathrm{AIC}$ (374.9; also $>2$ units smaller than the next term: carotenoid $\mathrm{X}$ esters, 381.2). See also figure $2 C$ (slopes in figures were obtained from raw data).

Esterified, free, and total carotenoids were also alternatively 

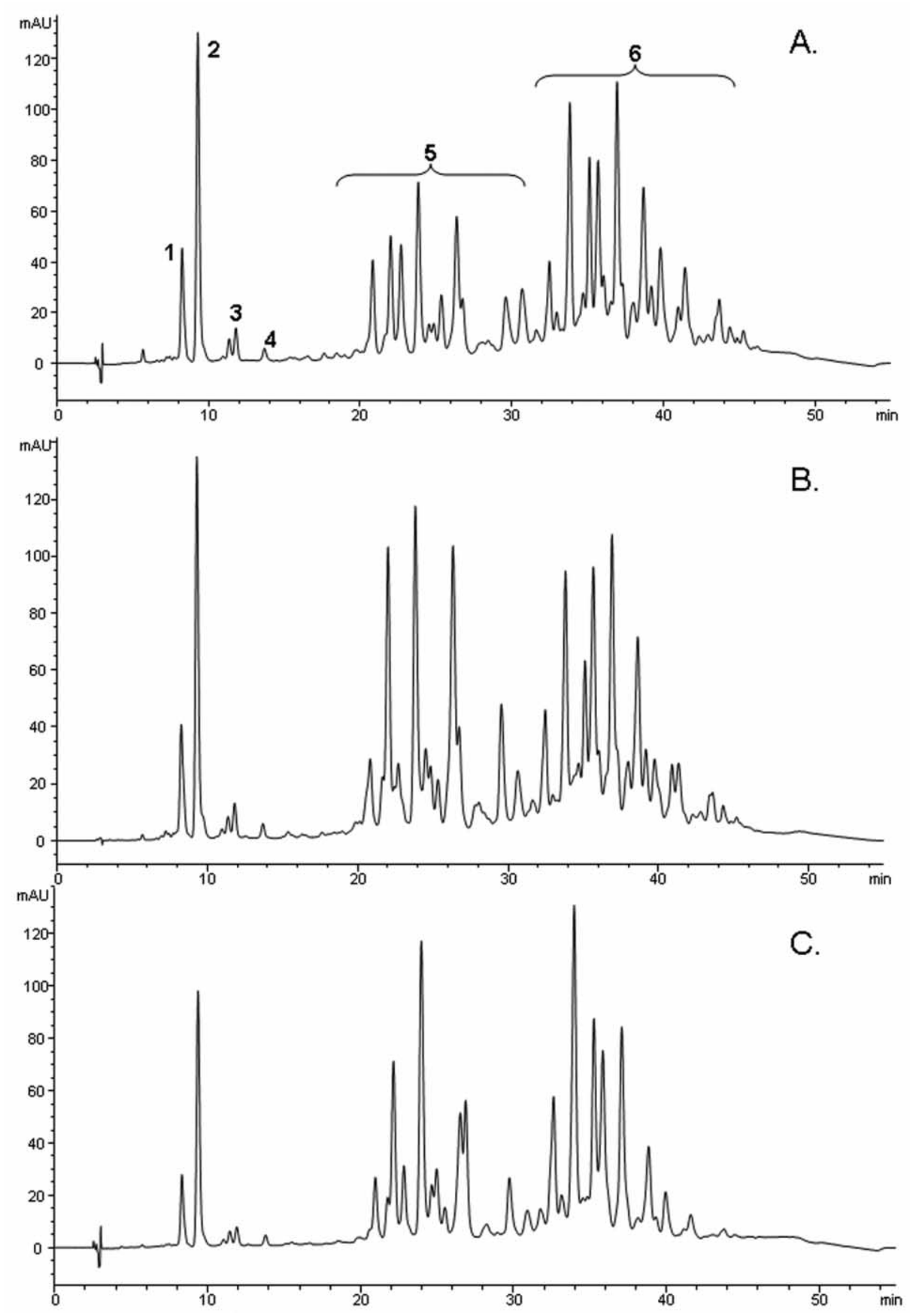

Figure 1. Illustrative chromatogram showing the different peaks identified in bills $(A)$, eye rings $(B)$, and legs $(C)$ of red-legged partridges. Numbers above peaks indicate carotenoid X (1), astaxanthin (2), lutein (3), cantaxanthin (4), carotenoid X and astaxanthin monoesters (5), and astaxanthin diesters (6).

tested as covariates in the redness models (fig. 3). In the bill, the three covariates explained color to a similar extent (esters: $F_{1,135}=5.51, \quad P=0.020$, slope $\pm \mathrm{SE}=0.235 \pm 0.100$, $\mathrm{AIC}=349.3, \quad \mathrm{ED}=3.5 \% ;$ free carotenoids: $F_{1,136}=4.99$, $P=0.027$, slope $\pm \mathrm{SE}=0.338 \pm 0.152$, AIC $=349, \mathrm{ED}=$ $3.7 \%$; total carotenoids: $F_{1,135}=5.67, P=0.019$, slope $\pm \mathrm{SE}=$ $0.268 \pm 0.113, \mathrm{AIC}=348.9, \mathrm{ED}=3.7 \%)$. In the eye ring, however, the level of esterified carotenoids was not significantly related to color $\left(F_{1,141}=2.75, P=0.100\right.$; $\left.\mathrm{AIC}=381.6\right)$, but the level of free carotenoids was the best predictor $\left(F_{1,140}=\right.$ 13.26, $P<0.001$, slope \pm SE: $0.611 \pm 0.168, \mathrm{AIC}=370.6$, $\mathrm{ED}=8.5 \%)$, followed by total carotenoids $\left(F_{1,141}=4.07\right.$, $P=0.045$, slope $\pm \mathrm{SE}=0.237 \pm 0.117, \mathrm{AIC}=380, \mathrm{ED}=$ $2.6 \%)$. The opposite was found when analyzing the legs, because 

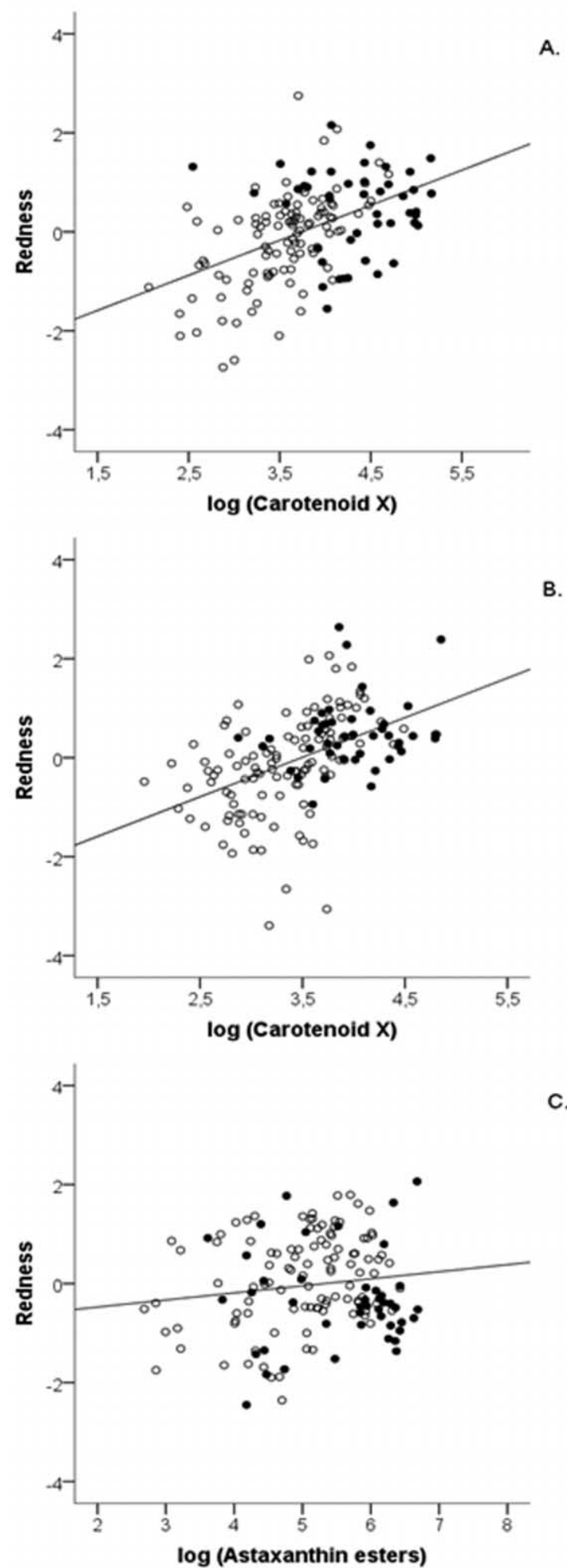

Figure 2. Relationship between redness and those variables that better explained color in bills $(A)$, eye rings $(B)$, and legs $(C)$ of red-legged partridges. Open circles are data from captive birds, whereas filled circles represent wild birds. Circles and slopes were obtained from raw data (i.e., without controlling for environment or random factors; see "Material and Methods" and "Results"). esterified carotenoid levels were highly correlated with redness $\left(F_{1,138}=10.79, \quad P=0.001\right.$, slope $\pm \mathrm{SE}=0.400 \pm 0.122$, $\mathrm{AIC}=375.1, \mathrm{ED}=7.3 \%$ ), whereas free carotenoid levels were not $\left(F_{1,138}=0.10, P=0.750 ;\right.$ AIC $\left.=384.3\right)$. Total carotenoid levels were also correlated with leg color $\left(F_{1,138}=8.93, P=\right.$ 0.003 , slope \pm SE: $0.441 \pm 0.148, E D=6.1 \%$ ), and its model did not differ in terms of AIC from that of esterified carotenoids $(\mathrm{AIC}=376.4)$.

When esterified and free carotenoids were simultaneously tested in color models, similar findings arose. Neither esterified $\left(F_{1,135}=0.84, P=0.361\right)$ nor free carotenoids $\left(F_{1,137}=0.34\right.$, $P=0.563)$ were initially associated with bill redness, but esterified carotenoids became significant $(P=0.020)$ when free carotenoids were removed following a backward stepwise procedure. Nonetheless, the two alternative models were equivalent in AIC. In the eye ring, total ester levels were not significantly related to redness $\left(F_{1,140}=0.49, P=0.483\right)$, but free carotenoid levels were $\left(F_{1,138}=10.8, P=0.001\right.$; slope \pm SE: $0.705 \pm$ $0.220)$. In contrast, esterified carotenoid levels were highly correlated with color in legs $\left(F_{1,137}=12.7, P=0.001\right.$; slope: $0.490 \pm 0.140)$, but free carotenoids were not $\left(F_{1,137}=1.94\right.$, $P=0.166)$.

\section{Differences in Age and Environments}

Most of the differences between age classes were detected exclusively in legs. Older birds had redder legs and showed significantly higher concentrations of all forms of carotenoids in that tissue, with the exception of free lutein, cantaxanthin, and astaxanthin monoesters (table 1). The only significant difference in other traits was the presence of higher levels of total carotenoid $\mathrm{X}$ in eye rings of yearlings. When testing the variability in esterification rates, only the esterified versus total carotenoid $\mathrm{X}$ rate in the bill was significantly different between age classes $\left(F_{1,36.3}=4.24, P=0.047\right)$, older partridges showing higher rates (mean \pm SE: $4.477 \pm 0.043$ vs. $4.500 \pm 0.042$, for yearlings and $\geq 1$-yr-old birds, respectively). Other ornaments and rates did not show significant results $(P>0.140$ for all).

Wild partridges showed redder bills and eye rings than captive individuals, but their legs did not differ significantly in color (table 2). With regard to pigment composition, no free carotenoid was specific for wild or captive birds. However, large differences in concentration were found, with wild birds showing higher levels of every free and esterified form of carotenoids in the three ornaments, with the exception of free cantaxanthin (table 2).

Wild birds also showed higher esterification rates (fig. 4; i.e., total esterified vs. total carotenoids), patterns being coherent among ornaments (bill: $F_{1,10}=8.47, P=0.016$; eye ring: $F_{1,9.21}=5.71, P=0.040$; legs: $\left.F_{1,7.99}=5.79, P=0.043\right)$. In the bill, the specific rate of esterified astaxanthin versus total astaxanthin also showed a significant difference in the same direction $\quad\left(F_{1,11.3}=5.02, \quad P=0.046 ; \quad 87.65 \% \pm 1.66 \% \quad\right.$ vs. $95.71 \% \pm 3.05 \%)$. Other traits and rates did not show significant differences between wild and captive birds $(P>0.24$ for 


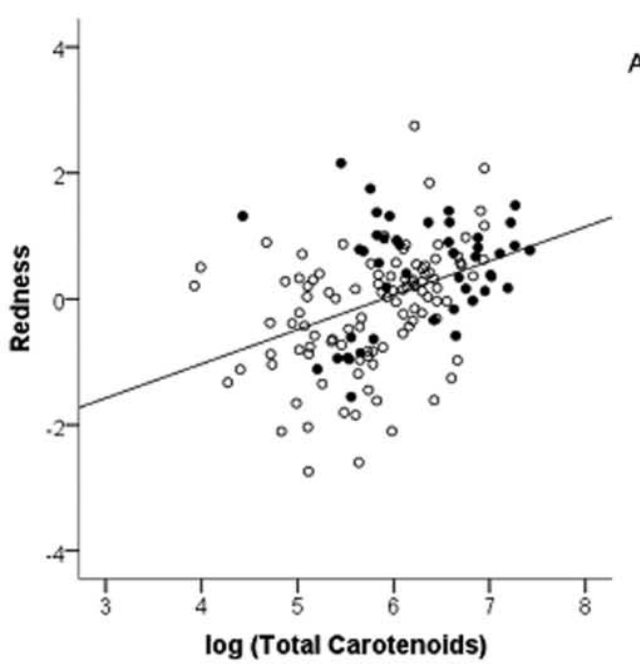

A.

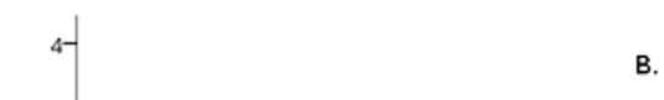

B.
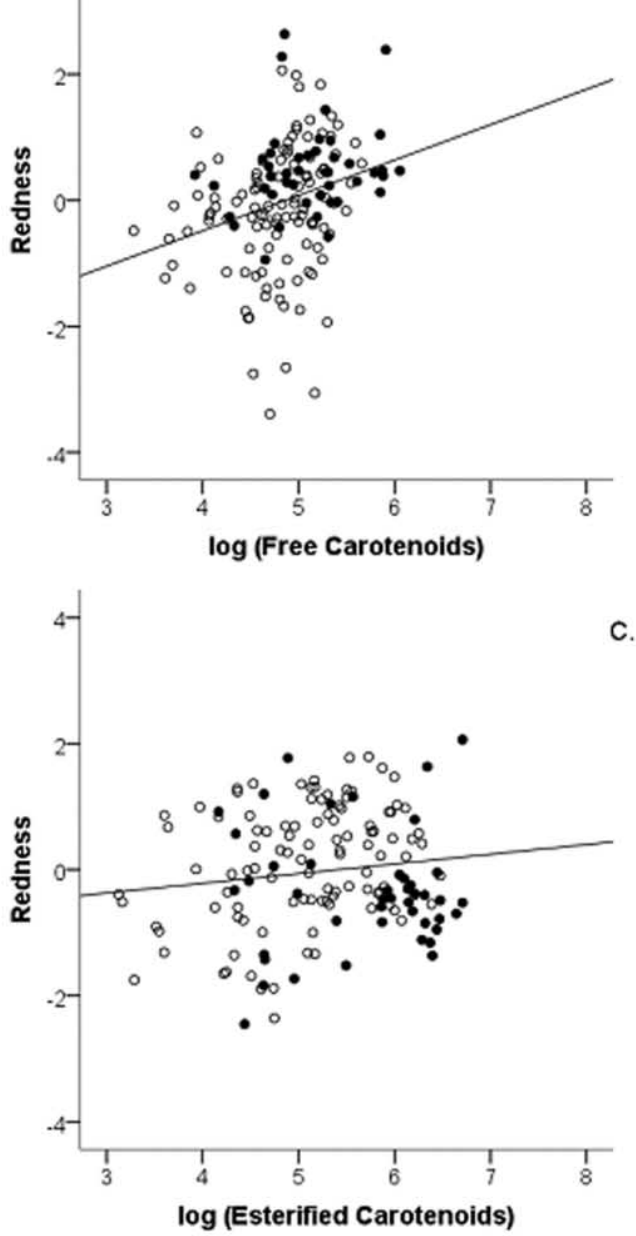

Figure 3. Relationship between redness and alternative carotenoiddependent variables in bills $(A)$, eye rings $(B)$, and legs $(C)$ of redlegged partridges. Open circles are data from captive birds, whereas filled circles represent wild birds. Circles and slopes were obtained from raw data (i.e., without controlling for environment or random factors; see "Material and Methods" and "Results"). all). The sex was removed from all the models testing the environmental effect $(P>0.20$ for all).

\section{Discussion}

Free and Esterified Carotenoids Explaining Color Variability

For some colored traits in red-legged partridges, coloration was significantly related to the concentration of either free or esterified carotenoids. It is unlikely that these forms of carotenoids actually differ in hue. Rather, the associations between carotenoid esterification and ornamental color likely reflect basic biochemical pathways that affect both the allocation of carotenoids to tissue and the levels of carotenoid esterification (Hill and Johnson 2012). This would ultimately imply that variability of total carotenoid levels in the ornaments among individuals could be in some way limited by the capacity to allocate only one of the two forms (free or esterified ones) to the trait, which may affect the balance between costs and benefits of carotenoid-based signaling (Lozano 1994; Hasson 1997; Hill 2006).

As far as we know, this is the first quantitative analysis of the relationship between carotenoid esterification levels and color expression in ornaments of any animal species. The only examples of a link between carotenoid esterification and color of animal integuments would be those about western rock lobsters Panulirus cygnusthree and black tiger prawns Penaeus monodon reported by Wade et al. $(2005,2008,2012)$ and Tume et al. (2009), respectively. Their results suggest that astaxanthin is stored in its esterified form on the carapace, with free astaxanthin levels determining differences in color between redder and paler animals, that is, the former showing higher free carotenoid values (Tume et al. 2009; Wade et al. 2012). However, Wade et al. $(2005,2008)$ reported previous findings supporting the opposite mechanism, that is, levels of esterified carotenoids explaining the color difference. In red-legged partridges, a single free form of carotenoid (carotenoid X) was the best explanatory variable of redness in two of the three ornaments (i.e., the head traits). This was observed despite the variety of carotenoids detected and the fact that most of them were esterified $(>80 \%)$. In legs, nonetheless, the best predictor was the level of esterified astaxanthin (i.e., the other main carotenoid in partridges' bare parts). In any case, our work differs from the cited studies on several points. First, there is an obvious phylogenetic distance among species. In crustaceans, free astaxanthin is mostly combined with binding proteins, creating macromolecular complexes (crustacyanins) that produce distinctive purple-blue colors (Helliwell et al. 2010). Second, variability in carapace coloration in these species is largely explained by crypsis (i.e., not by sexual selection) as the trait changes with the color of the substrate in the same individual (Wade et al. 2008; Tume et al. 2009). Finally, in the cited studies, conclusions were based on comparisons between two groups (redder vs. paler animals) of only a few animals ( $<6$ per group).

We observed a variable contribution of pigment esterification to coloration among ornaments. Eye ring redness was better explained by concentrations of free carotenoids, whereas leg 
Table 1: Differences in color and carotenoid composition of red ornaments between yearlings and older captive red-legged partridges

\begin{tabular}{|c|c|c|c|c|c|}
\hline \multirow[b]{2}{*}{ Variable } & \multicolumn{2}{|c|}{ Mean $\pm \mathrm{SE}$} & \multirow[b]{2}{*}{$F$} & \multirow[b]{2}{*}{ df } & \multirow[b]{2}{*}{$P$} \\
\hline & Yearlings & Older birds & & & \\
\hline \multicolumn{6}{|l|}{ Bill: } \\
\hline Redness & $-.278 \pm .264$ & $.169 \pm .205$ & 1.78 & 1,34 & .191 \\
\hline Total carotenoids & $5.829 \pm .571$ & $6.018 \pm .567$ & 2.16 & $1,35.3$ & .151 \\
\hline Total carotenoid X & $4.819 \pm .378$ & $5.003 \pm .373$ & 2.33 & $1,35.5$ & .136 \\
\hline Free carotenoid X & $3.837 \pm .277$ & $3.877 \pm .270$ & .08 & $1,35.9$ & .775 \\
\hline Monoesters of carotenoid X & $4.761 \pm .389$ & $4.957 \pm .384$ & 2.6 & $1,35.5$ & .116 \\
\hline Total astaxantin & $5.722 \pm .615$ & $5.918 \pm .611$ & 2.11 & $1,35.3$ & .155 \\
\hline Free astaxantin & $4.781 \pm .337$ & $4.820 \pm .331$ & .1 & $1,36.7$ & .775 \\
\hline Monoesters of astaxanthin & $4.710 \pm .345$ & $4.905 \pm .338$ & 2.01 & $1,35.8$ & .165 \\
\hline Diesters of astaxanthin & $5.481 \pm .783$ & $5.698 \pm .779$ & 1.78 & $1,35.2$ & .191 \\
\hline Esters of astaxanthin & $5.631 \pm .666$ & $5.838 \pm .662$ & 2.11 & $1,35.2$ & .156 \\
\hline Free lutein & $3.227 \pm .222$ & $3.278 \pm .208$ & .11 & $1,37.9$ & .745 \\
\hline Free cantaxanthin & $4.330 \pm .609$ & $4.420 \pm .606$ & .57 & $1,36.2$ & .456 \\
\hline \multicolumn{6}{|l|}{ Eye ring: } \\
\hline Redness & $.243 \pm .268$ & $-.147 \pm .208$ & 1.31 & 1,34 & .261 \\
\hline Total carotenoids & $5.610 \pm .745$ & $5.660 \pm .742$ & .14 & $1,35.2$ & .711 \\
\hline Total carotenoid X & $6.066 \pm .362$ & $5.786 \pm .357$ & 5.56 & $1,36.6$ & .024 \\
\hline Free carotenoid X & $3.322 \pm .411$ & $3.299 \pm .403$ & .02 & $1,35.8$ & .884 \\
\hline Monoesters of carotenoid X & $4.675 \pm .759$ & $4.558 \pm .756$ & .82 & $1,35.2$ & .372 \\
\hline Total astaxantin & $5.485 \pm .778$ & $5.563 \pm .772$ & .3 & $1,35.2$ & .59 \\
\hline Free astaxantin & $4.192 \pm .348$ & $4.233 \pm .342$ & .1 & $1,36.7$ & .757 \\
\hline Monoesters of astaxanthin & $4.603 \pm .495$ & $4.767 \pm .489$ & 1.03 & $1,36.6$ & .317 \\
\hline Diesters of astaxanthin & $5.077 \pm 1.073$ & $5.177 \pm 1.071$ & .44 & $1,35.1$ & .51 \\
\hline Esters of astaxanthin & $5.425 \pm .816$ & $5.510 \pm .813$ & .36 & $1,35.2$ & .554 \\
\hline Free lutein & $3.307 \pm .348$ & $3.488 \pm .344$ & 3.18 & $1,36.5$ & .083 \\
\hline Free cantaxanthin & $3.990 \pm .664$ & $4.140 \pm .661$ & 1.45 & $1,36.2$ & .237 \\
\hline \multicolumn{6}{|l|}{ Leg: } \\
\hline Redness & $-.576 \pm .274$ & $.393 \pm .239$ & 10.57 & 1,31 & .003 \\
\hline Total carotenoids & $5.093 \pm .477$ & $5.367 \pm .474$ & 5.84 & $1,41.3$ & .02 \\
\hline Total carotenoid X & $4.097 \pm .422$ & $4.510 \pm .415$ & 7.94 & $1,42.8$ & .007 \\
\hline Free carotenoid X & $2.993 \pm .0747$ & $3.182 \pm .059$ & 3.89 & 1,43 & .055 \\
\hline Monoesters of carotenoid X & $4.043 \pm .453$ & $4.458 \pm .447$ & 7.69 & $1,42.7$ & .008 \\
\hline Total astaxantin & $4.951 \pm .528$ & $5.230 \pm .525$ & 5.87 & $1,41.3$ & .02 \\
\hline Free astaxantin & $3.459 \pm .198$ & $3.950 \pm .179$ & 8.43 & $1,43.1$ & .006 \\
\hline Monoesters of astaxanthin & $4.140 \pm .222$ & $4.392 \pm .209$ & 2.9 & 1,43 & .096 \\
\hline Diesters of astaxanthin & $4.639 \pm .750$ & $4.973 \pm .748$ & 9.89 & $1,42.1$ & .003 \\
\hline Esters of astaxanthin & $4.841 \pm .590$ & $5.174 \pm .587$ & 8.13 & $1,42.2$ & .007 \\
\hline Free lutein & $3.007 \pm .106$ & $3.008 \pm .093$ & .01 & $1,40.7$ & .991 \\
\hline Free cantaxanthin & $4.004 \pm .356$ & $4.041 \pm .350$ & .09 & $1,41.7$ & .767 \\
\hline
\end{tabular}

Note. Redness is a standardized variable, whereas carotenoid-related variables were log transformed. Least square means $( \pm$ SE) were obtained from mixed models that included the year of analysis as a random factor $(P$ range: $0.121-$ 0.48; see "Material and Methods"). $P<0.05$ is indicated in boldface type.

redness was mostly linked to variability in esterified carotenoids. Bill redness was equally explained by both forms of carotenoids. Interestingly, eye rings also presented the highest esterification rates, although the difference among traits was relatively small (approximately 2\%). A certain dependence of color on the variability of low levels of free carotenoids might allow quick changes in redness (Tume et al. 2009; Wade et al. 2012). Ac- cordingly, we previously found in partridges that, when compared with bill color, eye ring redness is a better predictor of rapid (within a few days) physiological changes (Perez-Rodriguez 2008; Perez-Rodriguez and Viñuela 2008).

Nonetheless, a large part of variability in redness remained unexplained, perhaps because of reduced accuracy in measurements of carotenoid composition and color. We must con- 
Table 2: Differences between captive and wild red-legged partridges in color and carotenoid composition of red ornaments

\begin{tabular}{|c|c|c|c|c|c|}
\hline \multirow[b]{2}{*}{ Variable } & \multicolumn{2}{|c|}{ Mean $\pm \mathrm{SE}$} & \multirow[b]{2}{*}{$F$} & \multirow[b]{2}{*}{ df } & \multirow[b]{2}{*}{$P$} \\
\hline & Captive & Wild & & & \\
\hline \multicolumn{6}{|l|}{ Bill: } \\
\hline Redness & $-.237 \pm .236$ & $.381 \pm .225$ & 5.6 & $1,11.2$ & .037 \\
\hline Total carotenoids & $5.649 \pm .366$ & $6.434 \pm .360$ & 18.36 & $1,7.57$ & .003 \\
\hline Total carotenoid X & $4.324 \pm .313$ & $5.199 \pm .294$ & 11.34 & $1,7.08$ & .012 \\
\hline Free carotenoid X & $3.264 \pm .267$ & $4.191 \pm .241$ & 11.3 & $1,6.31$ & .014 \\
\hline Monoesters of carotenoid X & $4.284 \pm .317$ & $5.139 \pm .299$ & 11.33 & $1,7.13$ & .012 \\
\hline Total astaxantin & $5.520 \pm .404$ & $6.371 \pm .398$ & 16.94 & $1,8.63$ & .003 \\
\hline Free astaxantin & $4.402 \pm .234$ & $5.068 \pm .217$ & 9.5 & $1,7.35$ & .017 \\
\hline Monoesters of astaxanthin & $4.303 \pm .265$ & $5.176 \pm .247$ & 13.27 & $1,8.44$ & .006 \\
\hline Diesters of astaxanthin & $5.310 \pm .528$ & $6.221 \pm .527$ & 14.76 & $1,9.7$ & .003 \\
\hline Esters of astaxanthin & $5.447 \pm .439$ & $6.328 \pm .436$ & 17.69 & $1,9.02$ & .002 \\
\hline Free lutein & $3.211 \pm .173$ & $3.691 \pm .174$ & 17.27 & $1,6.78$ & .005 \\
\hline Free cantaxanthin & $4.043 \pm .473$ & $3.888 \pm .444$ & .16 & $1,7.43$ & .698 \\
\hline \multicolumn{6}{|l|}{ Eye ring: } \\
\hline Redness & $-.901 \pm .745$ & $-.082 \pm .739$ & 8.87 & $1,10.2$ & .014 \\
\hline Total carotenoids & $5.618 \pm .483$ & $6.559 \pm .485$ & 71.74 & $1,11.7$ & $<.001$ \\
\hline Total carotenoid X & $4.488 \pm .468$ & $5.373 \pm .464$ & 27.16 & $1,7.83$ & .001 \\
\hline Free carotenoid X & $3.053 \pm .275$ & $4.029 \pm .262$ & 22.28 & $1,9.98$ & .001 \\
\hline Monoesters of carotenoid X & $4.443 \pm .495$ & $5.323 \pm .492$ & 28.01 & $1,7.89$ & .001 \\
\hline Total astaxantin & $5.501 \pm .508$ & $6.504 \pm .511$ & 67.03 & $1,12.4$ & $<.001$ \\
\hline Free astaxantin & $4.041 \pm .232$ & $5.003 \pm .221$ & 30.93 & $1,8.88$ & $<.001$ \\
\hline Monoesters of astaxanthin & $4.591 \pm .314$ & $5.595 \pm .312$ & 48.08 & $1,9.62$ & $<.001$ \\
\hline Diesters of astaxanthin & $5.148 \pm .760$ & $6.169 \pm .766$ & 42.94 & $1,16.2$ & $<.001$ \\
\hline Esters of astaxanthin & $5.438 \pm .559$ & $6.440 \pm .564$ & 66.31 & $1,14.5$ & $<.001$ \\
\hline Free lutein & $3.394 \pm .182$ & $3.761 \pm .184$ & 9.7 & $1,9.9$ & .011 \\
\hline Free cantaxanthin & $3.979 \pm .470$ & $4.022 \pm .453$ & .02 & $1,7.28$ & .89 \\
\hline \multicolumn{6}{|l|}{ Leg: } \\
\hline Redness & $.077 \pm .179$ & $-.299 \pm .185$ & 2.37 & $1,9.33$ & .157 \\
\hline Total carotenoids & $5.178 \pm .369$ & $6.027 \pm .364$ & 26.31 & $1,10.9$ & $<.001$ \\
\hline Total carotenoid X & $4.109 \pm .336$ & $4.984 \pm .328$ & 24.95 & $1,10,5$ & $<.001$ \\
\hline Free carotenoid X & $2.724 \pm .150$ & $3.658 \pm .135$ & 21.38 & $1,10.4$ & .001 \\
\hline Monoesters of carotenoid X & $4.063 \pm .355$ & $4.942 \pm .348$ & 25.11 & $1,10.5$ & .001 \\
\hline Total astaxantin & $5.016 \pm .417$ & $5.934 \pm .411$ & 21.15 & $1,10.6$ & .001 \\
\hline Free astaxantin & $3.476 \pm .247$ & $4.553 \pm .227$ & 21.26 & $1,10.7$ & .001 \\
\hline Monoesters of astaxanthin & $4.044 \pm .216$ & $5.031 \pm .202$ & 23.85 & $1,10.5$ & .001 \\
\hline Diesters of astaxanthin & $4.637 \pm .683$ & $5.581 \pm .681$ & 21.6 & $1,11.2$ & .001 \\
\hline Esters of astaxanthin & $4.943 \pm .457$ & $5.882 \pm .453$ & 21.74 & $1,10.8$ & .001 \\
\hline Free lutein & $2.951 \pm .0785$ & $3.205 \pm .0908$ & 11.26 & $1,11.8$ & .001 \\
\hline Free cantaxanthin & $3.860 \pm .289$ & $3.756 \pm .269$ & .18 & $1,7.99$ & .686 \\
\hline
\end{tabular}

Note. Redness is a standardized variable, whereas carotenoid-related variables were log transformed. Least square means $( \pm \mathrm{SE}$ ) were obtained from mixed models that included the identity of the population and the year of analysis as random factors ( $P$ range: $0.020-0.45$; see "Material and Methods"). $P<0.05$ is indicated in boldface type.

sider the difficulties inherent to homogenization and pigment extraction in highly keratinized and heterogeneous tissues. On the other hand, color was estimated on one side of each trait (we assumed a perfect bilateral symmetry) and only on a portion of the trait, because some parts are difficult to assess (e.g., lower mandible and fingers). Additionally, proteins, melanins, and nanostructures in the tissues may have contributed to color variability. Carotenoids can be bound to proteins to form complexes (carotenoproteins) described in plants, some invertebrates (crustacyanin), and the human retina (Zagalsky 1985; Dreon et al. 2003; Heras et al. 2007). As a simple way for testing the occurrence of carotenoproteins, heating tissues usually leads to a rapid increase in redness as a result of protein denaturalization (Britton et al. 1981; Cianci et al. 2002). We tried this 

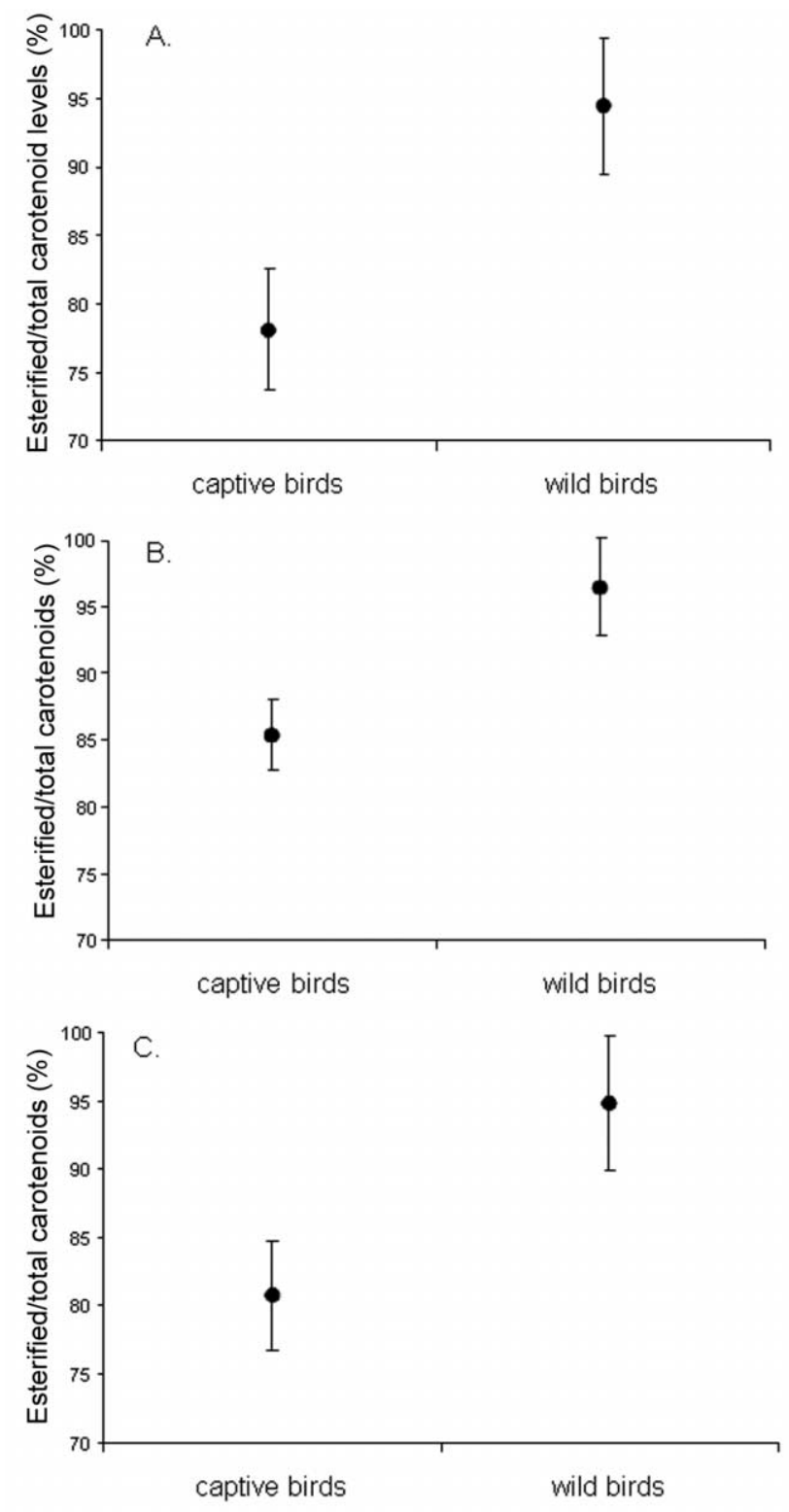

Figure 4. Differences in esterification rates of carotenoid compounds in the ornaments (bill $[A]$, eye rings $[B]$, and legs $[C]$ ) of captive and wild red-legged partridges. Least square means $( \pm S E)$ were obtained from the models (see "Material and Methods").

rough procedure on partridges' bare parts, but no apparent change was observed. With regard to melanins, a biochemical and spectrophotometrical technique for melanin detection (Toral et al. 2008) was used on partridge ornaments, but results did not suggest melanin presence (E. García-de Blas, unpublished data). Finally, nanostructures produced by keratin (bill and legs) and collagen (eye rings) may produce "structural colors," including UV (nonvisible) color (reviewed in Prum 2006). It has been suggested that UV reflectance in feathers interacts with carotenoid-based colorations (Shawkey and Hill 2005; McGraw 2006). We did not assess UV color in partridge traits. Nonetheless, we must consider that galliforms have only reduced sensitivity to UV (they are violet-sensitive as opposed to UV-sensitive species; Cuthill 2006). Furthermore, previous work in red-legged partridges has shown that UV color is proportionally less abundant than red color, and the interindividual variability in the red fraction of the spectrum is much larger than variability in the UV fraction (Pérez-Rodríguez 2008; Alonso-Alvarez and Galván 2012). Lastly, carotenoid-based and structural colors might ultimately covary without producing any emergent signaling property, leading only to redundant information (Candolin 2003; Shawkey and Hill 2005; Butler et al. 2011; Pike et al. 2011).

\section{Differences between Ages and Environments}

At the proximate level, differences between ages and environments in concentrations of free and esterified carotenoids in the ornaments can originate from differences in (1) diet, (2) intestinal absorption, (3) blood transport, (4) uptake rates by ornamental tissues, and (5) carotenoid biotransformation (reviewed in McGraw 2006).

In the case of age-related variability, differences were almost exclusively detected in the legs. Older birds showed redder tarsi and higher concentrations of nearly every compound in this trait. Birds of known age exclusively came from captivity, all with ad lib. access to a standard diet. Assuming equal carotenoid intake among age classes, the first possibility can thus be discarded. In contrast, intestinal absorption efficiency and blood transport may be influenced by the absorption and circulation of lipids, particularly cholesterol (Surai 2002; McGraw and Parker 2006), and evidence from poultry indicates that cholesterol levels increase with age (Dikmen and Sahan 2007). Oxidative stress in blood could also reduce the availability of carotenoids for pigmentation (Pérez-Rodríguez 2009). In red-legged partridges, young birds have higher oxidative stress in blood than do middle-aged birds (Alonso-Alvarez et al. 2010), and exposure to oxidative stress reduces plasma carotenoid levels and redness (Alonso-Alvarez and Galván 2011). Finally, age-related differences could have arisen from a selective mortality of paler birds during their first years of life (Pagani-Nunez and Senar 2012). Nonetheless, why are age-related differences only detected in the legs?

Carotenoid deposition in ornaments was initially attributed to passive diffusion into cells (carotenoids are liposoluble; Britton et al. 2004). McGraw (2006), however, has suggested that differences in amounts of carotenoid-binding proteins (i.e., those forming carotenoproteins) could explain variability among tissues. Alternatively or additionally, specific protein receptors could be involved. It is known that a scavenger receptor type 1 (SR-B1) binds to high-density lipoproteins, which are the main xanthophyll carriers, thus potentially regulating carotenoid levels in specific tissues (Kiefer et al 2002; During and Harrison 2007). Interestingly, the presence of SR-B1 in a carotenoid-based ornament (the red bill of quelea Quelea quelea) has recently been demonstrated (Walsh et al. 2012). From an evolutionary perspective, we might suggest that, under a 
multiple signaling scenario (Candolin 2003), leg redness could mostly serve as an index of individual age in partridges, whereas head traits could be used to estimate individual quality (AlonsoAlvarez et al. 2012). However, previous findings suggest that red ornaments in the head of red-legged partridges may also allow the differentiation of individual age, at least when comparing middle-aged individuals with older individuals (AlonsoAlvarez et al. 2009). In any case, we must be cautious with the extent of our conclusions regarding age-related differences, given that we could only distinguish two rough age classes (yearlings and $\geq 1$-yr-old birds) on a reduced subsample of birds from one captive population.

In contrast to age-related comparisons, significant differences between wild and captive birds strongly emerged in every ornament. Wild birds showed redder traits (with the exception of legs) and higher levels of all forms of carotenoids. The previously mentioned mechanisms influencing carotenoid deposition in the ornaments may also explain these findings. As found in other bird species (Hill 1992, 2006), carotenoid intake is expected to be higher in wild partridges, given their access to green plants that contribute significantly to their diet during winter and early spring (Cramp and Simmons 1980), which is when sample collection took place. Higher amounts of lipids in the natural diet might also have favored higher pigment absorption by the intestine (Surai 2002), and higher levels of antioxidants may have enhanced carotenoid protection during absorption and transport (e.g., vitamins A, C, and E and selenium; Catoni et al. 2008; Hill and Johnson 2012). Captive partridges, in turn, have higher amounts of intestinal parasites (Villanúa et al. 2006; Mougeot et al. 2009) than wild partridges captured in our study area (Villanúa et al. 2008; L. PérezRodríguez, unpublished data), and these parasites are known to decrease both carotenoid absorption and deposition in ornaments (Allen 1987; Martínez-Padilla et al. 2007; Mougeot et al. 2009). Moreover, the different pace of life of wild and captive birds is likely to result in metabolic and endocrine differences. Wild birds would maintain higher rates of physical exercise. Although strenuous exercise could increase oxidative stress, moderate physical activity seems to reduce free radical production and strengthen the antioxidant system (Metcalfe and Alonso-Alvarez 2010), conferring greater protection against carotenoid bleaching in wild birds. Paler bare parts in captive birds have also been associated with higher levels of those hormones triggered by stress (i.e., corticoids; McGraw et al. 2011).

The esterification rates of carotenoids also differed between environments and ages, although the latter difference was only significant with respect to the bill. Little is known about the regulation and metabolism of carotenoid esters in animals. Studies involving humans show that esterified xanthophylls are hydrolyzed by enzymes (e.g., carboxyl ester lipases) when crossing the enterocyte barrier (Maiani et al. 2009; FernandezGarcía et al. 2012 and references therein). In poultry, esters of xanthophylls are apparently fully hydrolyzed before being passed to circulation (Breithaupt et al. 2003). Thus, the amount of esterified carotenoid in the diet should not influence carotenoid esterification in ornaments. Interestingly, we have not detected any esterified carotenoid in the blood of red-legged partridges (E. García-de Blas, unpublished data), which suggests that reesterification is directly performed in the colored trait. Variability could thus be attributed to (1) individual capacity to allocate free fatty acids to the ornaments and (2) the ability to combine them with free carotenoids in situ. The role of enzymes (probably lipases), not only in hydrolyzing carotenoid esters but in forming them, has been suggested in plants and human studies, although it has not been demonstrated (Wingerath et al. 1998; Mellado-Ortega and Hornero-Méndez 2012). Age- or environmental-associated factors could affect enzymatic activity. Accordingly, oxidative stress seems to stimulate lipases in human immune cells (Maingrete and Renier 2003) and is also linked to development, aging, and many environmental stressors (Metcalfe and Alonso-Alvarez 2010). This effect on the esterification rate may be similar to that in the carotenoid-derived vitamin $\mathrm{A}$, which tends to undergo a shift from retinyl esters toward free retinol in the liver of wild mammals affected by lead-induced oxidative stress (RodríguezEstival et al. 2011).

In summary, the fact that the amount and proportion of esterified carotenoids show significant variability and contribute to trait coloration encourages additional research. In situ metabolism and esterification of ingested carotenoids could play a role in the change of appearance of ornaments. Esterification improves pigment stability (Pérez-Gálvez and Mínguez-Mosquera 2005; Rao et al. 2007), particularly against heat and photodegradation (Subagio et al. 1999), which are able to bleach carotenoid-based ornaments (Blount and Pike 2012). However, whether carotenoid esterification influences carotenoid properties, such as immunostimulatory and antioxidant activities, is still unknown (Pérez-Gálvez and MínguezMosquera 2005). To understand how individual quality affects endocrine and enzymatic control systems regulating pigment esterification is also necessary. This would ultimately allow the identification of costs and benefits of carotenoid esterification and the determination of its potential role in the expression of reliable carotenoid-based signals of quality.

\section{Acknowledgments}

We thank Dámaso Hornero-Méndez and two anonymous referees for suggestions to improve this work and Ester Ferrero and Laura Ramirez for their help with the laboratory work and photographic analyses. We also thank the owners and managers of the farms and wild areas that supplied partridges. Particularly, we thank the staff of Finca Dehesa Galiana (Universidad de Castilla-La Mancha). We thank Sarah Young for her review of the English text. Esther García-de Blas was supported by a predoctoral grant (JAE-PRE program) from the Consejo Superior de Investigaciones Científicas cofinanced by Fondo Social Europeo. Lorenzo Pérez-Rodríguez was supported by a "Juan de la Cierva" postdoctoral contract from the Spanish 
Ministerio de Ciencia e Innovación (JCI-2008-2059). This study was funded by Consejería de Educación y Ciencia, Junta de Comunidades de Castilla la Mancha (PII1I09-0271-5037), and Ministerio de Economía y Competitividad (CGL2009-10883C02-02) from the Spanish government.

\section{APPENDIX}

\section{Euthanasia and Color Measurement by Digital Photography}

Birds from captivity were euthanized by means of intravenous anesthesia (xylazine chloridrate; Rompun, Bayer) and an intramuscular euthanasic (embutramide, mebezonium iodide, and tetracaine hydrochloride; T-61 Intervet, Alcobendas, Spain), following the advice of the veterinarian staff of Instituto de Investigación en Recursos Cinegéticos and ethical guidelines in concert with current Spanish laws.

Color of bills, eye rings, and legs was assessed by digital photography. This procedure has repeatedly been used in redlegged partridges (Alonso-Alvarez et al. 2008; Alonso-Alvarez and Galván 2011). Hue obtained by the Foley and Van Dam (1984) algorithm is a measure of color location that describes the range of wavelengths that most contribute to the reflectance spectrum of an object. It is usually measured in degrees of a circular scale (color wheel) and is commonly used to capture color variation in carotenoid-based bare parts with a single parameter (McGraw et al. 2006; McGraw 2007; Gautier et al. 2008; McGraw and Toomey 2010).

We have previously determined repeatabilities (Lessells and Boag 1987) for this technique on duplicate photographs (i.e., moving the bird and again placing it under the camera; $r>$ 0.90, for each trait; 48 birds, 96 pictures; Alonso-Alvarez and Galván 2011).

To know the correlation between our measurements and those performed with devices that also assess the UV spectrum, 118 bills and eye rings were simultaneously measured by digital photography and by using a portable reflectance spectrometer (Minolta CM-2600D, Tokyo). Repeatabilities of this technique (subsample, $n=50$ ) analyzed three times were 0.93 and 0.60 for bills and eye rings, respectively $(P<0.001$ for all). Leg color could not be assessed by spectrometry because the probe of the device did not adapt well to leg surfaces. Hue measurements obtained from digital pictures and reflectance spectrometry were significantly correlated (bill: $r=0.73, P<0.001$; eye ring: $r=0.68, P<0.001)$.

\section{Literature Cited}

Allen P.C. 1987. Physiological response of chicken gut tissue to coccidial infection: comparative effects of Eimeria acervulina and Eimeria mitis on mucosal mass, carotenoid content, and brush border enzyme activity. Poult Sci 66:1306-1315.

Alonso-Alvarez C., S. Bertrand, B. Faivre, O. Chastel, and G.
Sorci. 2007. Testosterone and oxidative stress: the oxidation handicap hypothesis. Proc Biol Sci 274:819-825.

Alonso-Alvarez C. and I. Galván. 2011. Free radical exposure creates paler carotenoid-based ornaments: a possible interaction in the expression of black and red traits. PLoS ONE 6:e19403.

Alonso-Alvarez C., L. Pérez-Rodríguez, M.E. Ferrero, E. Garcíade Blas, F. Casas, and F. Mougeot. 2012. Adjustment of female reproductive investment according to male carotenoid-based ornamentation in a gallinaceous bird. Behav Ecol Sociobiol 66:731-742.

Alonso-Alvarez C., L. Pérez-Rodríguez, J.T. García, and J. Viñuela. 2009. Testosterone-mediated trade-offs in the old age: a new approach to the immunocompetence handicap and carotenoid-based sexual signaling. Proc R Soc B 276:20932101.

Alonso-Álvarez C., L. Pérez-Rodríguez, J.T. García, J. Viñuela, and R. Mateo. 2010. Age and breeding effort as sources of individual variability in oxidative stress markers in a bird species. Physiol Biochem Zool 83:110-118.

Alonso-Alvarez C., L. Pérez-Rodríguez, R. Mateo, O. Chastel, and J. Viñuela. 2008. The oxidation handicap hypothesis and the carotenoid allocation trade-off. J Evol Biol 21:1789-1797.

Blas J., L. Pérez-Rodríguez, G.R. Bortolotti, J. Viñuela, and T.A. Marchant. 2006. Testosterone increases bioavailability of carotenoids: new insights into the honesty of sexual signalling. Proc Natl Acad Sci USA 103:18633-18637.

Blesbois E., M. Lessire, I. Grasseau, J.M. Hallouis, and D. Hermier. 1997. Effect of dietary fat on the fatty acid composition and fertilizing ability of fowl semen. Biol Reprod 56:12161220.

Blount J.D. and T.W. Pike. 2012. Deleterious effects of light exposure on immunity and sexual coloration in birds. Funct Ecol 26:37-45.

Breithaupt D.E., P. Weller, and M. Grashorn. 2003. Quantification of carotenoids in chicken plasma after feeding free or esterified lutein and capsanthin using high-performance liquid chromatography and liquid chromatography-mass spectrometry analysis. Poult Sci 82:395-401.

Britton G., G.M. Armitt, S.Y.M. Lau, A.K. Petal, and C.C. Shone. 1981. Carotenoproteins. Pp. 237-251 in Britton G. and T.W. Goodwin, eds. Carotenoids: chemistry and biochemistry. Pergamon, Oxford.

Britton G., S. Liaaen-Jensen, H. Pfander, eds. 2004. Carotenoids handbook. Birkhaüser, Basel.

Brush A.H. 1981. Carotenoids in wild and captive birds. Pp. 539-562 in Bauerfeind C., ed. Carotenoids as colorants and vitamin A precursors. Academic Press, New York.

Butler M.W., M.B. Toomey, and K.J. McGraw. 2011. How many color metrics do we need? evaluating how different colorscoring procedures explain carotenoid pigment content in avian bare-part and plumage ornaments. Behavl Ecol Sociobiol 65:401-413.

Candolin U. 2003. The use of multiple cues in mate choice. Biol Rev 78:575-95.

Casagrande S., C. Dijkstra, J. Tagliavini, V.C Goerlich, and 
T.G.G. Groothuis. 2011. Differential effects of testosterone, dihydrotestosterone and estradiol on carotenoid deposition in an avian sexually selected signal. J Comp Physiol A 197: $1-13$.

Catoni C., A. Peters, and H.M. Schaefer. 2008. Life history trade-offs are influenced by the diversity, availability and interactions of dietary antioxidants. Anim Behav 76:11071119.

Chew B.P. and J.S. Park. 2004. Carotenoid action on the immune response. J Nutr 134(suppl.):257S-261S.

Chow C.K., ed. 2007. Fatty acids in foods and their health implications. Third edition. CRC, Bocca Raton, FL.

Cianci M., P.J. Rizkallah, A. Olczak, J. Raftery, N.E. Chayen, P.F. Zagalsky, and J.R. Helliwell. 2002. The molecular basis of the coloration mechanism in lobster shell: beta-crustacyanin at 3.2-A resolution. Proc Natl Acad Sci USA 99:97959800.

Costantini D., A. Fanfani, and G. DellOmo. 2008. Effects of corticosteroids on oxidative damage and circulating carotenoids in captive adult kestrels (Falco tinnunculus). J Comp Physiol B 178:829-835.

Cramp S. and K.E.L. Simmons. 1980. The birds of the western Palearctic. Oxford University Press, Oxford.

Cuthill I.C. 2006. Color perception. Pp. 3-40 in Hill G.E. and K.J. McGraw. Bird coloration: mechanisms and measurements. Harvard University Press, Cambridge, MA.

Czeczuga B. 1979. Carotenoids in the skin of certain species of birds. Comp Biochem Physiol B 6:107-109.

Das U.N. 2006. Essential fatty acids: biochemistry, physiology and pathology. Biotechnol J 1:420-439.

del Val E., J. Quesada, and J.C. Senar. 2010. Age-related differences in a carotenoid-based coloration trait are due to within-individual changes in great tits Parus major. Ardea 98:179-184.

del Val E., C. Senar, J. Garrido-Fernández, M. Jarén, A. Borràs, J. Cabrera, and J.J. Negro. 2009. The liver but not the skin is the site for conversion of a red carotenoid in a passerine bird. Naturwissenschaften 96:797-801.

Deviche P. 2008. Season-, sex- and age-specific accumulation of plasma carotenoid pigments in free-ranging white-winged crossbills Loxia leucoptera. J Avian Biol 39:283-292.

Dikmen B.Y. and U. Sahan. 2007. Correlations between breeder age, egg cholesterol content, blood cholesterol level and hatchability of broiler breeders. Br Poult Sci 48:98-103.

Dreon M.S., H. Heras, and R.J. Pollero. 2003. Metabolism of ovorubin, the major egg lipoprotein from the apple snail. Mol Cell Biochem 243:9-14.

During A. and E.H. Harrison. 2007. Mechanisms of provitamin A (carotenoid) and vitamin A (retinol) transport into and out of intestinal Caco-2 cells. J Lipid Res 48:2283-2294.

Endler J.A. 1980. Natural selection on color patterns in Poecilia reticulata. Evolution 34:76-91.

Fernández-García E., I. Carvajal-Lérida, M. Jarén-Galán, J. Garrido-Fernández, A. Pérez-Gálvez, and D. Hornero-Méndez. 2012. Carotenoids bioavailability from foods: from plant pig- ments to efficient biological activities. Food Res Int 46:438450.

Foley J.D. and A. Van Dam. 1984. Fundamentals of interactive computer graphics. Addison-Wesley, Reading, MA.

Freeman-Gallant C.R., C.C. Taff, D.F. Morin, P.O. Dunn, L. Whittingham, and S.M. Tsang. 2010. Sexual selection, multiple male ornaments, and age- and condition-dependent signaling in the common yellowthroat. Evolution 64:10071017.

Fridolfsson A. and H. Ellegren. 1999. A simple and universal method for molecular sexing of non-ratite birds. J Avian Biol 30:116-121.

García-de Blas E., R. Mateo, J. Viñuela, and C. Alonso-Alvarez. 2011. Identification of carotenoid pigments and their fatty acid esters in an avian integument combining HPLC-DAD and LC-MS analyses. J Chrom B 879:341-348.

Gautier P., M. Barroca, S. Bertrand, C. Eraud, M. Gaillard, M. Hamman, S. Motreuil, G. Sorci, and B. Faivre. 2008. The presence of females modulates the expression of a carotenoid-based sexual signal. Behav Ecol Sociobiol 62: 1159-1166.

Goodwin T.W. 1984. The biochemistry of the carotenoids. Vol. 2. Animals. Chapman \& Hall, London.

Gortazar C., R. Villafuerte, and M. Martin. 2000. Success of traditional restocking of red-legged partridge for hunting purposes in areas of low density of northeast Spain Aragon. Z Jagdwiss 46:23-30.

Granado F., B. Olmedilla, E. Gil-Martínez, and I. Blanco. 1998. Lutein ester in serum after lutein supplementation in human subjects. Br J Nutr 80:445-449.

Grether G.F, J. Hudon, and D.F. Millie. 1999. Carotenoid limitation of sexual coloration along an environmental gradient in guppies. Proc R Soc B 266:1317-1322.

Hasson O. 1997. Towards a general theory of biological signaling. J Theor Biol 185:139-156.

Hawkins G.L., G.E. Hill, A. Mercadante. 2012. Delayed plumage maturation and delayed reproductive investment in birds. Biol Rev 87:257-274.

Helliwell J.R. 2010. The structural chemistry and structural biology of colouration in marine crustacea. Crystallogr Rev 16:231-242.

Heras H., M.S. Dreon, S. Ituarte, and R.J. Pollero. 2007. Egg carotenoproteins in neotropical Ampullariidae (Gastropoda: Arquitaenioglossa). Comp Biochem Physiol C 146:158-167.

Hill G.E. 1992. Proximate basis of variation in carotenoid pigmentation in male house finches. Auk 109:1-12.

- 2006. Enviromental regulation of ornamental coloration. Pp. 507-560 in Hill G.E. and K.J. McGraw. Bird coloration: mechanisms and measurements. Harvard University Press, Cambridge, MA.

Hill G.E. and J. Johnson. 2012. The vitamin A-redox hypothesis: a biochemical basis for honest signaling via carotenoid pigmentation. Am Nat 180:E127-E150.

Hudon J. 1994. Showiness, carotenoids and captivity: a comment on Hill. Auk 111:218-221.

Hulbert A. and R. Pamplona. 2007. Life and death: metabolic 
rate, membrane composition, and life span of animals. Physiol Rev 87:1175-1213.

Kiefer C., E. Sumser, M.F. Wernet, and J.V. Lintig. 2002. A class B scavenger receptor mediates the cellular uptake of carotenoids in Drosophila. Proc Natl Acad Sci USA 99:1058110586.

Leeuwenburgh C.J. and W. Heinecke. 2001. Oxidative stress and antioxidants in exercise. Curr Med Chem 8:829-838.

Lemoine Y. and B. Schoefs. 2010. Secondary ketocarotenoid astaxanthin biosynthesis in algae: a multifunctional response to stress. Photosynth Res 106:155-177.

Lensing M., J.D. van der Klis, T. Fabri, A. Cazemier, and A.J. Else. 2010. Efficacy of a lactylate on production performance and intestinal health of broilers during a subclinical Clostridium perfringens infection. Poult Sci 89:2401-2409.

Lessells C.M. and P.T. Boag. 1987. Unrepeatable repeatabilities: a common mistake. Auk 104:116-121.

Lindstrom K. and J. Lundstrom. 2000. Male greenfinches (Carduelis chloris) with brighter ornaments have higher virus infection clearance rate. Behav Ecol Sociobiol 48:44-51.

Littell R.C., G.A. Milliken, W.W. Stroup, R.D. Wolfinger, and O. Schabenberger. 2006. SAS for mixed models. 2nd ed. SAS Institute, Cary, NC.

Lozano G.A. 1994. Carotenoids, parasites, and sexual selection. Oikos 70:309-311.

Lyon B.E. and R.D. Montgomerie. 1986. Delayed plumage maturation in passerine birds: reliable signaling by subordinate. Evolution 40:605-615.

Maiani G., M.P.J. Castón, G. Catasta, E. Toti, I.G. Cambrodón, A. Bysted, F. Granado-Lorencio, et al. 2009. Carotenoids: actual knowledge on food sources, intakes, stability and bioavailability and their protective role in humans. Mol Nutr Food Res 53(suppl.):S194-S218.

Maingrette F. and G. Renier. 2003. Leptin increases lipoprotein lipase secretion by macrophages: involvement of oxidative stress and protein kinase C. Diabetes 52:2121-2128.

Martínez-Padilla J., F. Mougeot, L. Pérez-Rodríguez, and G.R. Bortolotti. 2007. Nematode parasites reduce carotenoidbased signalling in male red grouse. Biol Lett 3:161-164.

Martinez-Padilla J., F. Mougeot, L.M.I. Webster, L. Pérez-Rodríguez, and S.B. Piertney. 2010. Testing the interactive effects of testosterone and parasites on carotenoid-based ornamentation in a wild bird. J Evol Biol 23:902-913.

McGraw K.J. 2004. Colorful songbirds metabolize carotenoids at the integument. J Avian Biol 35:471-476.

2006. Mechanics of carotenoid-based coloration. Pp. 177-242 in Hill G.E. and K.J. McGraw. Bird coloration: mechanisms and measurements. Harvard University Press, Cambridge, MA.

2007. Dietary mineral content influences melaninbased ornamental coloration. Behav Ecol 18:137-142.

. 2009. Identifying anatomical sites of carotenoid metabolism in birds. Naturwissinschaften 96:987-988.

McGraw K.J., E. Adkins-Regan, and R.S. Parker. 2002. Anhydrolutein in the zebra finch: a new, metabolically derived carotenoid in birds. Comp Biochem Physiol B 132:811-818.
McGraw K.J., S.M. Correa, and E. Adkins-Regan. 2006. Testosterone upregulates lipoprotein status to control sexual attractiveness in a colorful songbird. Behav Ecol Sociobiol 60: 117-122.

McGraw K.J., G.E. Hill, R. Stradi, and R.S. Parker. 2001. The influence of carotenoid acquisition and utilization on the maintenance of species-typical plumage pigmentation in male American goldfinches (Carduelis tristis) and northern cardinals (Cardinalis cardinalis). Physiol Biochem Zool 74: 843-852.

McGraw K.J., L. Kristen, and A. Lewin. 2011. The effect of capture-and-handling stress on carotenoid-based beak coloration in zebra finches. J Comp Physiol A 197:683-691.

McGraw K.J. and R.S. Parker. 2006. A novel lipoproteinmediated mechanism controlling sexual attractiveness in a colorful songbird. Physiol Behav 87:103-108.

McGraw K.J. and M.B. Toomey. 2010. Carotenoid accumulation in the tissues of zebra finches: predictors of integumentary pigmentation and implications for carotenoid allocation strategies. Physiol Biochem Zool 83:97-109.

Metcalfe N.B. and C. Alonso-Alvarez. 2010. Oxidative stress as a life-history constraint: the role of reactive oxygen species in shaping phenotypes from conception to death. Funct Ecol 24:984-996.

Millán J., C. Gortázar, and R. Villafuerte. 2003. Does supplementary feeding affect organ and gut size of wild red-legged partridges Alectoris rufa? Wildl Biol 9:1999-2003.

Miller N.J., J. Sampson, L.P. Candeias, P.M. Bramley, and C.A. Rice-Evans. 1996. Antioxidant activities of carotenes and xanthophylls. FEBS Lett 384:240-242.

Møller A.P., C. Biard, J.D. Blount, D.C. Houston, P. Ninni, N. Saino, and P.F. Surai. 2000. Carotenoid-dependent signals: indicators of foraging efficiency, immunocompetence or detoxification ability? Avian Poult Biol Rev 11:137-159.

Mougeot F., L. Pérez-Rodríguez, N. Sumozas, and J. Terraube. 2009. Parasites, condition, immune responsiveness and carotenoid-based ornamentation in male red-legged partridge Alectoris rufa. J Avian Biol 40:67-74.

Mozaffarian D., R. Micha, and S. Wallace. 2010. Effects on coronary heart disease of increasing polyunsaturated fat in place of saturated fat: a systematic review and meta-analysis of randomized controlled trials. PLoS Med 7:e1000252.

Murphy T.G, M.F. Rosenthal, R. Montgomerie, and K.A. Tarvin. 2009. Female American goldfinches use carotenoid-based bill coloration to signal status. Behav Ecol 20:1348-1355.

Nagao A. 2011. Absorption and metabolism of dietary carotenoids. BioFactors 37:83-87.

Negro J.J., J. Figuerola, J. Garrido, A.J. Green. 2001. Fat stores in birds: an overlooked sink for carotenoids pigments? Funct Ecol 15:297-303.

Nelson R.J. 2011. An introduction to behavioral endocrinology. 4th ed. Sinauer, Sunderland, MA.

Pagani-Núñez E. and J.C. Senar. 2012. Changes in carotenoidbased plumage colour in relation to age in European serins Serinus serinus. Ibis 154:155-160.

Pérez-Gálvez A. and M.I. Mínguez-Mosquera. 2005. Esterifi- 
cation of xanthophylls and its effect on chemical behavior and bioavailability of carotenoids in the human. Nutr Res 25:631-640.

Pérez-Rodríguez L. 2008. Carotenoid-based ornamentation as a dynamic but consistent individual trait. Behav Ecol Sociobiol 62:995-1005.

- 2009. Carotenoids in evolutionary ecology: re-evaluating the antioxidant role. BioEssays 31:1116-1126.

Pérez-Rodríguez L., F. Mougeot, and C. Alonso-Alvarez. 2010. Carotenoid-based coloration predicts resistance to oxidative damage during immune challenge. J Exp Biol 213:1685-1690.

Pérez-Rodríguez L., F. Mougeot, C. Alonso-Alvarez, J. Blas, J. Viñuela, and G.R. Bortolotti. 2008. Cell-mediated immune activation rapidly decreases plasma carotenoids but does not affect oxidative stress in red-legged partridges (Alectoris rufa). J Exp Biol 211:2155-2161.

Pérez-Rodriguez L. and J. Viñuela. 2008. Carotenoid-based bill and eye ring coloration as honest signals of condition: an experimental test in the red-legged-partridge (Alectoris rufa). Naturwissenschaften 95:821-830.

Peters A. 2007. Testosterone and carotenoids: an integrated view of trade-offs between immunity and sexual signalling. Bioessays 29:427-430.

Peters A., K. Delhey, S. Andersson, H. van Noordwijk, and M.I. Forschler. 2008. Condition-dependence of multiple carotenoid-based plumage traits: an experimental study. Funct Ecol 22:831-839.

Pike T.W., B. Bjerkeng, J.D. Blount, J. Lindstro, and N.B. Metcalfe. 2011. How integument colour reflects its carotenoid content: a stickleback's perspective. Funct Ecol 25:297-304.

Pintea A., H. Diehl, C. Momeu, L. Aberle, and C. Socaciu. 2005. Incorporation of carotenoid esters into liposomes. Biophys Chem 118:7-14.

Prum R.O. 2006. Anatomy, physics and evolution of structural colors. Pp. 295-353 in Hill G.E. and K.J. McGraw. Bird coloration: mechanisms and measurements. Harvard University Press, Cambridge, MA.

Prum R.O. and R. Torres. 2003. Structural coloration of avian skin: convergent evolution of coherently scattering dermal collagen arrays. J Exp Biol 206:2409-2429.

Rao A., R. Sarada, and G.A. Ravishankar. 2007. Stabilization of astaxanthin in edible oils and its use as an antioxidant. J Sci Food Agric 87:957-965.

Rodríguez-Estival J., M. Martinez-Haro, L. Monsalve-González, and R. Mateo. 2011. Interactions between endogenous and dietary antioxidants against $\mathrm{Pb}$-induced oxidative stress in wild ungulates from a $\mathrm{Pb}$ polluted mining area. Sci Total Environ 409:2725-2733.

San-Jose L.M., F. Granado-Lorencio, and P.S. Fitze. 2012. Vitamin E, vitamin A, and carotenoids in male common lizard tissues. Herpetologica 68:88-99.

SAS Institute. 2001. SAS/STAT software: changes and enhancements, version 8.2. SAS, Cary, NC.

Schielzeth H., B. Kempenaers, H. Ellegren, and W. Forstmeier. 2011. QTL linkage mapping of zebra finch beak color shows an oligogenic control of a sexually selected trait. Evolution 66:18-30.

Schweiggert U., C. Kurz, A. Schieber, and R. Carle. 2007. Effects of processing and storage on the stability of free and esterified carotenoids of red peppers (Capsicum annuum L.) and hot chilli peppers (Capsicum frutescens L.). Eur Food Res Technol 225:261-270.

Senar J.C., A.P. Møller, I. Ruiz, J.J. Negro, J. Broggi, and E. Hohtola. 2010. Specific appetite for carotenoids in a colorful bird. PLoS ONE 5:e10716.

Shawkey M.D. and G.E. Hill. 2005. Carotenoids need structural colours to shine. Biol Lett 1:121-124.

Stahl W. and H. Sies. 2003. Antioxidant activity of carotenoids. Mol Asp Med 24:345-351.

Stradi R., J. Hudon, G. Celentano, and E. Pini. 1998. Carotenoids in bird plumage: the complement of yellow and red pigments in true woodpeckers (Picinae). Comp Biochem Physiol B 120:223-230.

Subagio A., H. Wakaki, and N. Morita. 1999. Stability of lutein and its myristate esters. Biosci Biotechnol Biochem 63:17841786.

Surai P.F. 2002. Natural antioxidants in avian nutrition and reproduction. Nottingham University Press, Nottingham.

Toral G.M., J. Figuerola, and J.J. Negro. 2008. Multiple ways to become red: pigment identification in red feathers using spectrometry. Comp Biochem Physiol B 150:147-152.

Tume R.K., A.L. Sikes, S. Tabrett, and D.M. Smith. 2009. Effect of background colour on the distribution of astaxanthin in black tiger prawn (Penaeus monodon): effective method for improvement of cooked colour. Aquaculture 296:129-135.

Tyczkowski J.K. and P.B. Hamilton. 1986. Absorption, transport, and deposition in chickens of lutein diesters, a carotenoid extracted from marigold (Tagetes erecta) petals. Poult Sci 65:1526-1531.

Villanúa D., L. Pérez-Rodríguez, F. Casas, V. Alzaga, P. Acevedo, J. Viñuela, and C. Gortázar. 2008. Sanitary risks of red-legged partridge releases: introduction of parasites. Eur J Wildl Res 54:199-204.

Villanúa D., L. Pérez-Rodríguez, C. Gortázar, U. Höfle, and J. Viñuela. 2006. Avoiding bias in parasite excretion estimates: the effect of sampling time and type of faeces. Parasitology 133:251-259.

Wade N.M., M. Anderson, M.J. Sellars, R.K. Tume, N.P. Preston, and B.D. Glencross. 2012. Mechanisms of colour adaptation in the prawn Penaeus monodon. J Exp Biol 215:343350.

Wade N.M., K.C. Goultier, K.J. Wilson, M.R. Hall, and B.M. Degnan. 2005. Esterified astaxanthin levels in lobster epithelia correlate with shell colour intensity: potential role in crustacean shell colour formation. Comp Biochem Physiol B 141:307-313.

Wade N.M., R. Melville-Smith, B.M. Degnan, and M.R. Hall. 2008. Control of shell colour changes in the lobster, Panulirus cygnus. J Exp Biol 211:1512-1519.

Wade N.M., A. Tollenaere, M.R. Hall, and B.M. Degnan. 2009. 
Evolution of a novel carotenoid-binding protein responsible for crustacean shell color. Mol Biol Evol 26:1851-1864.

Walsh N., J. Dale, K.J. McGraw, M.A. Pointer, and N.I. Mundy. 2012. Candidate genes for carotenoid coloration in vertebrates and their expression profiles in the carotenoidcontaining plumage and bill of a wild bird. Proc R Soc B 279:58-66.

Wathes D.C., D.R.E. Abayasekara, and R.J. Aitken. 2007. Polyunsaturated fatty acids in male and female reproduction. Biol Reprod 77:190-201.
Weber H. 1961. Über die ursache des verlustes der roten federfarbe bei gekäfigten birkenzeisigen. J Ornithol 102:158-163.

Wedekind C., P. Meyer, M. Frischknecht, U.A. Niggle, and H. Pfander. 1998. Different carotenoids and potential information content of red coloration of male three-spined stickleback. J Chem Ecol 24:787-801.

Wingerath T, H. Sies, and W. Stahl. 1998. Xanthophyll esters in human skin. Arch Biochem Biophys 355:271-274.

Zagalsky P.F. 1985. Invertebrate carotenoproteins. Methods Enzymol 111:216-247. 